\title{
The Distribution and Phylogeny of Aluminium Accumulating Plants in the Ericales
}

\author{
S. Jansen ${ }^{1}$, T. Watanabe ${ }^{2}$, P. Caris ${ }^{1}$, K. Geuten ${ }^{1}$, F. Lens ${ }^{1}$, N. Pyck ${ }^{1}$, and E. Smets ${ }^{1}$ \\ ${ }^{1}$ Laboratory of Plant Systematics, Institute of Botany and Microbiology, K.U.Leuven, Kasteelpark Arenberg 31, 3001 Leuven, Belgium \\ ${ }^{2}$ Graduate School of Agriculture, Hokkaido University, Sapporo, 0608589 Japan
}

Received: August 1, 2003; Accepted: April 20,2004

\begin{abstract}
The distribution of aluminium (Al) accumulation in the Ericales is surveyed, based on semi-quantitative tests of 114 species and literature data. Al accumulation mainly characterises the families Diapensiaceae, Pentaphylacaceae, Symplocaceae, Ternstroemiaceae, and Theaceae. Al accumulation is consistently present or absent in most families examined, but the character appears to be more variable in a few taxa (e.g., Lecythidaceae, Myrsinaceae). Although the interfamilial relationships within the Ericales require further research, the ability to accumulate high levels of Al appears to show considerable taxonomic significance. While the majority of Al accumulating Ericales includes woody, tropical plants, the feature is remarkably present in several herbaceous Diapensiaceae, which have a distribution in cold to temperate areas. The association of different mycorrhizae types with plant roots is suggested to play a role in the exclusion of high Al levels from the shoot.
\end{abstract}

Key words: Aluminium accumulation, Ericales, phylogeny, Diapensiaceae, Pentaphylacaceae, Symplocaceae, Ternstroemiaceae, Theaceae.

\section{Introduction}

A high proportion of trivalent $\mathrm{Al}^{3+}$ ions generally becomes bioavailable and detrimental to plants when the soil pH falls below 5.5 in acid soils (Marschner, 1995). The majority of native plants growing in acid soils avoid the toxic effects of high Al levels by excluding this metal from their shoot tissues, although several crop plants are well known to be sensitive to high levels of soluble Al (Foy et al., 1978; Roy et al., 1988; Kochian, 1995). Indeed, Al toxicity forms the primary factor limiting production of wheat, corn, barley, and soybean in acid soils. Moreover, about $5 \%$ of angiosperms take up $\mathrm{Al}$ in their aboveground tissues in quantities far above the average of $200 \mathrm{mg} \mathrm{kg}^{-1}$. These plants have developed special mechanisms for the internal detoxification of $\mathrm{Al}$ in their shoots (Jansen et al., 2002 a, 2004; Watanabe and Osaki, 2002). According to Chenery (1946, $1948 \mathrm{a}, \mathrm{b})$, plants that have Al levels of at least

Plant Biology 6 (2004): $498-505$

(c) Georg Thieme Verlag KG Stuttgart · New York

ISSN $1435-8603 \cdot$ DOI 10.1055/s-2004-820980
$1000 \mathrm{mg} \mathrm{kg}^{-1}$ in their leaf dry matter can be defined as Al accumulators.

Al accumulating plants have mainly been studied from an ecological and physiological point of view because of substantial questions about the possible significance of $\mathrm{Al}$ accumulation. Since little attention has been paid to the systematic distribution and phylogenetic significance of $\mathrm{Al}$ accumulators, we have previously investigated the evolution of $\mathrm{Al}$ accumulation in the Rubiaceae (Gentianales) and Melastomataceae (Myrtales) (Jansen et al., 2000a, b, 2003; Jansen et al., 2002 b). These two families show by far the highest number of $\mathrm{Al}$ accumulators in angiosperms. The order Ericales represents the third largest group of $\mathrm{Al}$ accumulating plants. It is well known, for instance, that $\mathrm{Al}$ accumulation is present in the tea bush (Camellia sinensis L.), in which Al levels range from 5000 to $30000 \mathrm{mg} \mathrm{kg}^{-1}$ in mature leaves (Matsumoto et al., 1976). The commercial tea plant belongs to the Theaceae family, which is now included in the enlarged order Ericales (APG II, 2003; Smets and Pyck, 2003). Chenery (1955) has already paid extensive attention to $\mathrm{Al}$ accumulation in the tea bush and several others have investigated the distribution, concentration, and speciation of $\mathrm{Al}$ in tea leaves (Memon et al., 1981; Nagata et al., 1992, 1993; Echlin, 1996, 1999; Ruan and Wong, 2001). Furthermore, the occurrence of $\mathrm{Al}$ accumulation has been studied in families such as the Symplocaceae, Diapensiaceae, and Theaceae (Yoshii and Jimbo, 1932), but no study has surveyed this feature in the entire order Ericales.

Interest in studying $\mathrm{Al}$ compounds has increased over recent years due to the possible role of $\mathrm{Al}$ in neurodegenerative disorders such as Alzheimer's disease, although this link is still debatable (Exley, 2001, 2003). Since tea is the second most-consumed beverage in the world after water, it is probably the most important single source of dietary Al for many people. Accordingly, several studies have investigated the impact of tea on human health (Flaten and Ødegård, 1988; Flaten, 2002; Wong et al., 2003). A better understanding of the distribution of $\mathrm{Al}$ accumulation and its underlying physiological mechanisms may serve as a basis for the development of more resistant crop plants. It may also contribute to forest management, soil improvement, and remediation of degraded lands in tropical rain forests or savannas. 
This paper aims to illustrate the distribution and evolution of $\mathrm{Al}$ accumulators in the order Ericales. Since our knowledge of $\mathrm{Al}$ accumulators is limited to a few substantial contributions published more than 50 years ago, we have analysed 114 species from most families distinguished within the Ericales. A summary of the literature data allowed us to compare the new data with earlier results. The phylogenetic significance of $\mathrm{Al}$ accumulation in the order is evaluated based on the recent molecular phylogenetic studies of Anderberg et al. (2002), Bremer et al. (2002), and Geuten et al., 2004. Finally, some physiological, chemical, and ecological aspects are briefly discussed, linking a wide range of topics to the distribution of accumulators and non-accumulators in the study group. Indeed, a multidisciplinary approach is required to better understand the biology of $\mathrm{Al}$ accumulating plants.

\section{Materials and Methods}

Herbarium leaves of the Ericales were collected from the herbarium of the National Botanic Garden of Belgium (BR). Leaf material for the Lissocarpaceae, Pellicieraceae, Sladeniaceae, and Tertrameristaceae was not available. All specimens tested are listed in Table $\mathbf{1}$. We have analysed only one specimen for most species because the presence of $\mathrm{Al}$ accumulation is generally consistent at the species level (Jansen et al., 2002a, 2004). High Al concentrations in leaves were detected using the "aluminon" test as described by Chenery (1948 b) and followed by Jansen et al. (2000a, 2002 b). This simple but adequate test permits assessment by intensity of colour to arrange the specimens tested according to $\mathrm{Al}$ accumulators (crimson to dark red or red colour) or non-accumulators (colour varying from pink to yellow or dark brown). The distribution of $\mathrm{Al} \mathrm{ac-}$ cumulating taxa was then plotted on three trees using MacClade 4.0 (Maddison and Maddison, 2000).

Several Ericales have been reported to accumulate more than $10000 \mathrm{mg} \mathrm{kg}^{-1}$ in their leaves and can therefore be labelled as $\mathrm{Al}$ "hyperaccumulators". Since precise quantitative data on the $\mathrm{Al}$ content were not obtained using the semi-quantitative spot tests, we use the term "accumulators" throughout this paper for all accumulating plants, even if the exact $\mathrm{Al}$ content could be far above $10000 \mathrm{mg} \mathrm{kg}^{-1}$.

\section{Results}

A summary of the distribution of $\mathrm{Al}$ accumulation in the Ericales is presented in Table 1, including our own tests and literature data.

Only 12 out of the 114 species tested by us appeared to show a positive result, indicating $\mathrm{Al}$ accumulation in the leaves. All other species were found to be negative. The majority of the families included non-accumulators, but the feature appeared to be strongly present in the Diapensiaceae, Pentaphylacaceae, Symplocaceae, Ternstroemiaceae, and most Theaceae. Al accumulators were also found in at least two genera of the Lecythidaceae (including Scytopetalaceae), namely Brazzeia and Pierrina, although most genera in this family were negative. There were no new records of $\mathrm{Al}$ accumulating families, but the feature was reported for the first time in the genus Pierrina (Lecythidaceae).
In general, there was good agreement between our data and earlier tests. However, the genera Galax and Shortia (Diapensiaceae), Diospyros (Ebenaceae), Brazzeia (Lecythidaceae), $R a-$ panea (Myrsinaceae), and Adinandra (Ternstroemiaceae) gave negative results according to our analyses, while positive results were previously recorded by Chenery (1948a, b) and Masunaga et al. (1998).

\section{Discussion}

\section{The distribution of Al accumulators}

The combination of our new analyses and literature data provides a good overview of the occurrence of $\mathrm{Al}$ accumulation in the Ericales. As illustrated by the new record of $\mathrm{Al}$ accumulation in Pierrina, further sampling will probably reveal other previously unknown Al accumulators, but the overall distribution seems to be clear. The data obtained may allow us to distinguish two different groups: (1) families in which $\mathrm{Al}$ accumulation is exclusively absent, and (2) families in which $\mathrm{Al}$ accumulation is partly to almost entirely present. Most families in the Ericales belong to the group of non-accumulators, as the character is exclusively absent in 18 out of 27 families (Table $\mathbf{1}$ ). The $\mathrm{Al}$ accumulating group includes the families Diapensiaceae, Pentaphylacaceae, Symplocaceae, Ternstroemiaceae, and Theaceae, which are thought to include strong, possibly absolute or obligate $\mathrm{Al}$ accumulators. Obligate $\mathrm{Al}$ accumulators can be defined as species in which the $\mathrm{Al}$ content of the shoot is constantly above $1000 \mathrm{mg} \mathrm{kg}^{-1}$, irrespective of the concentration of soluble $\mathrm{Al}$ in the soil or seasonal changes (Jansen et al., 2002 a).

While the presence or absence of $\mathrm{Al}$ accumulation is of constant occurrence in most families, the character appears to be more variable in the Lecythidaceae and Myrsinaceae. The low number of $\mathrm{Al}$ accumulators and the mixed occurrence of positive and negative results may suggest that facultative rather than absolute accumulators occur in these families. The internal $\mathrm{Al}$ concentration in facultative accumulators more or less reflects the external soil level and thus may depend on environmental conditions such as soil acidity and availability of soluble Al. It was not possible, however, to consider environmental aspects in this study because precise ecological data on the herbarium specimens studied were not available. Although exact analytical data may help to clarify the sporadic occurrence of $\mathrm{Al}$ accumulation, this feature seems to be restricted to Rapanea within the Myrsinaceae, and to Brazzeia and Pierrina within the Lecythidaceae (including Scytopetalaceae).

Furthermore, Al accumulation appears to be absent or very rare in the Ebenaceae and Sapotaceae, since all data based on Chenery's "aluminon" test are negative. The single records of $\mathrm{Al}$ accumulation in the Ebenaceae and Sapotaceae include a relatively high Al level of $15270 \mathrm{mg} \mathrm{kg}^{-1}$ in an unidentified species of Diospyros (Ebenaceae), while Al concentrations in Diospyros sumatrana Miq., Ganua mottleyana Pierre ex Dubard (Sapotaceae), and Palaquium obovatum Engl. (Sapotaceae) were only slightly above the $1000 \mathrm{mg} \mathrm{kg}^{-1}$ criterion (Masunaga et al., 1998). Moreover, Masunaga et al. (1998) proposed a threshold of $3000 \mathrm{mg} \mathrm{kg}^{-1}$ to differentiate Al accumulators from non-accumulators. 
Table 1 Distribution of Al accumulation in the Ericales; classification is according to Anderberg et al. (2002) and Bremer et al. (2002); data are compiled from Yoshii and Jimbo $(1932)^{1}$, Hutchinson $(1943)^{2}$, Chenery $(1948 \mathrm{a}, \mathrm{b})^{3}$, Webb $(1954)^{4}$, Masunaga et al. $(1998)^{5}$, and own tests; taxa with at least one Al accumulating specimen are printed in bold; if known, the nominator gives the number of Al accumulating specimens, the denominator is the total number of specimens tested; $\mathrm{W}=\mathrm{Al}$ accumulation in wood, according to Kukachka and Miller (1980)

\begin{tabular}{|c|c|}
\hline Family & Genera and specimens tested for Al accumulation \\
\hline Actinidiaceae & $\begin{array}{l}\text { Actinidia }(0 / 2)^{3} \text {; Clematoclethra scandens (Franch.) Maxim. subsp. tomentella (Franch.) Y. C. Tang et Q. Y. Xiang, China, } \\
\text { Si Chuan, Guan Xian, Menkasnshan, W. Zhang-tao et al. 8700290; Saurauia oblancilimba Quisumb., Philippines, } \\
\text { Mt. Nañgaoto, Luzon, M. S. Sulit } 7686\end{array}$ \\
\hline Balsaminaceae & $\begin{array}{l}(0 / 2)^{1} \text {; Impatiens pallida Nutt., USA, J. H. Wibbe, BR-S. P. } 844 \text { 226; Hydrocera triflora (L.) Wight and Arn., Sri Lanka, } \\
\text { Welisara, Ragama, A. G. Robyns } 7260\end{array}$ \\
\hline Clethraceae & $\begin{array}{l}(0)^{3} \text {; Clethra lancifolia Turcz., Philippines, Mt. Bulusan, Sorsogon Province, Luzon, G. E. Edaño and H. Gutierrea 37839; } \\
\text { Purdiaea nutans Planch., Colombia, Prov. of Ocana, L. Schlim } 344\end{array}$ \\
\hline Cyrillaceae & $\begin{array}{l}(0 / 1)^{3} \text {; Cliftonia monophylla (Lam.) Sarg., USA, Florida, Bay County, Pine Log State, ca. } 10 \text { miles N of Laguna Beach } \\
\text { along FL 79, F. H. Utech 92-014; Cyrilla racemiflora L., USA, Texas, Hardin County, P. Fryxell } 2997\end{array}$ \\
\hline Diapensiaceae & $\begin{array}{l}\text { Berneuxia }(1 / 1)^{3} \text {; Diapensia }(1 / 1)^{1} ;(1 / 1)^{2} ;(2 / 2)^{3} ; \text { D. Iapponica L., Canada, University of Sherbrooke, A. Legault and } \\
\text { S. Brisson 7786; Galax }(1 / 1)^{2} ;(1 / 1)^{3} ; \text { G. aphylla L., USA, Virginia, Isle of Wight County, R. D. Bray } 84-27 ; \text { Pyxidanthera } \\
(1 / 1)^{3} ;(1 / 1)^{2} \text {; P. barbulata Michx., origin unknown, R. K. Godfrey and R. N. White 7099; Shortia }(1 / 1)^{1} ;(2 / 2)^{2} ;(3 / 3)^{3} \text {; } \\
\text { S. uniflora Maxim., Japan, Mt. Daihiyama, Yamashiro, H. Kubo, M. Togasi and T. Matsuoka } 1336\end{array}$ \\
\hline Ebenaceae & $\begin{array}{l}(0 / 1)^{1} \text {; }(0 / 2)^{3} \text {; Diospyros }(2 / 2)^{5} \text {; }(0 / 8)^{4} \text {; D. cargillia F. Muell., Australia, Camberwarra, A. Meebold 2898; D. suluensis Merr., } \\
\text { Borneo, Tawao, Elphinstone Prov., A. D. E. Elmer 21204; D. oubatchensis Kosterm., New Caledonia, Pouebo, Mandjelia, } \\
\text { MacKee 37782; D. ovalifolia Wight, Sri Lanka, Madhu Road Sanctary, L. Bernardi 15347; Euclea crispa (Thunb.) Gürke, } \\
\text { Malawi, Mlanje Mt. Forest, Nyasaland, J. D. Chapman 457; E. polyandra (L. f.) E. Mey ex Hiern, South Africa, Bo Kouga, } \\
\text { Eastern Cape, R. D. A. Bay 1372; E. racemosa Murr, South Africa, Hagelkraal poort, SW Cape, L. Huigo } 1593\end{array}$ \\
\hline Ericaceae & $\begin{array}{l}\text { Leucothoe }(0 / 1)^{1} \text {; Gaultheria }(0 / 4)^{3} ;(0 / 9)^{4} ;(0 / 44)^{3} \text {; Rhododendron japonicum C. K. Schneid., Japan, Honshu, H. Kanai } \\
\text { and H. Ohashi 731209; R. japonicum Suringar, Japan, Kadzo ranch, Nishinomaki-mura Kanra-gun, Kodsoke, Honshu, } \\
\text { S. Kobayashi 16428; R. vidalli Rolfe, Philippines, Mt. Data, Luzon, G.L. Alcasid 1838; R. vidalli Rolfe, Philippines, Bontoc, } \\
\text { Luzon, M. Vanoverbergh 70; Vaccinium bracteatum Thunb., Japan, Hondo, Yamamoto in Settsu, M. Togasi 640; } \\
\text { V. bracteatum Thunb., Japan, Kyushu, Mt. Shira-tahe, Sumo, Shimoagatagun, Tsushima Island, H. Ohashi, H. Ohba and } \\
\text { Y. Tateishi 29; V. dunalianum Wight, Sikkim, India, J. D. H., BR-S.P. } 834466\end{array}$ \\
\hline
\end{tabular}

Fouquieriaceae

Lecythidaceae (including Scytopetalaceae)

$(0)^{3}$; Fouquieria shrevei I. M. Johnst., Mexico, Coahuila, P. Fryxell 3027

$(0)^{3}$; Asteranthos brasiliensis Desf., Colombia, Rio Guainia, Puerto Colombia, Schultes, Baker and Cabrera 18214; Brazzeia (3/3) ${ }^{3}$; B. congoensis Baill., Democratic Republic of Congo-Kinshasa, P. N. Odzala, Mbandza, D. Champluvier 5275, BR-S.P. 129 736; B. soyauxii (Oliv.) Tiegh., Cameroon, N’Kolandom, J. J. F. E. de Wilde 8156; Eschweilera pachysepala (Spruce) Mart. ex Berg, Brazil, basin of Rio Madeira, Amazonas, Mun. Humayata, B. A. Krukoff 7116; Gustavia hexapetala (Aubl.) A. C. Sm., Surinam, Zanderij I, P. J. Eyma 4370; Lecythis lanceolata Poir., Brazil, A. Glaziou 658; Pierrina zenkeri Engl., Cameroon, Kribi, J. J. Bos 5422; P. zenkeri Engl., Cameroon, Kribi, J. J. Bos 3856; Rhaptopetalum coriaceum Oliv., Nigeria, Ekinta, P. P. C. van Neer, 1110a; R. evrardii Germ., Democratic Republic of Congo-Kinshasa, Botsima, D. Matchu-Mandje 1058; Scytopetalum pierreanum (De Wild.) Tiegh., origin unknown, Kalina, E. Jans 559; S. tieghemii Hutch. and Dalziel, Ivory Coast, Chevalier 33057

Lissocarpaceae Lissocarpa $(0)^{3}$

Maesaceae

Maesa edulis C. T. White, New Caledonia, Boësa Island, R. Iserentant 9776; M. formosana Mez, Taiwan, Pref. Hualie, Tienhsiang, T. Shimizu and M. T. Kao 10536; M. japonica Moritzi and Zoll., Japan, Hondo, Minomo in Settsu, M. Togasi 1261

Marcgraviaceae Marcgravia $(0 / 3)^{3}$; Norantea $(0 / 2)^{3} ;$ N. delpiniana Wittm., Brazil, Chapéu, Braço Norte, Espirito Santo, G. and M. Hatschbach 597282, BR-S.P. 834 498; Ruyschia (0/2) ${ }^{3}$; Souroubea (0/1)3 ; S. corallina (Mart.) de Roon, Brazil, Amazonas, Mun. São Paulo de Olivença, B. A. Krukoff 8699a; S. guianensis Aubl. subsp. amazonica (Mart.) de Roon, Brazil, Amazonas, Mun. Humayta, near Livramento, B. A. Krukoff 6725

Myrsinaceae $(0 / 4)^{1}$; $(0 / 8)^{4}$; (0/15) ; Ardisia pulchella Mez, Philippines, Mt. Nañgaoto, Luzon, M. D. Sulit 7713; Discocalyx sp., Netherlands New Guinea, Kebar valley, ca. 100 km N of Manokwari, P. van Royen 3920; Glaux maritma L., Iran, Route de Kerman à Bam, J. Léonard 6025; G. maritima L., France, Cayeux sur mer Somme, R. Dechamps 3014; Myrsine capitellata Wall., Sri Lanka, Handepan Ella Plains, A. Kostermans 28116; M. guianensis (Aubl.) Kuntze, USA, Florida, Nixon-Lewis Hammock, J. K. Small and C. A. Mosier 6391; Rapanea $(4 / 7)^{3} ;$ R. acrosticta Mez, New Guinea, Morobe District, Yimziang, Clemens 2372; R. diminuta Mez, New Caledonia, Paita, R. Schlechter 14915; R. macrophylla Mez, New Caledonia, Mt. Humboldt, R. Schlechter 15293; R. neriifolia Mez, Japan, Hondo, Irozaki, Idzu, M. Togasi 447; Tapeinosperma vieillardii Hook. f., New Caledonia, ou-Hinna, R. Schlechter 15700

Pellicieraceae Pentaphylacaceae Pelliciera $(0 / 1)^{3}$

Pentaphylax (3/3) ${ }^{3}$; P. euryoides Gardner and Champ., Hong Kong, Sha Lo Shan, Wa Mei Tong Village, Sin-Jung District, Y. W. Taam 251; P. euryoides Gardner and Champ., Hong Kong, Hauce, BR-S.P. 834465

Polemoniaceae $(0 / 3)^{3}$; Ipomopsis aggregatata (Pursh) V. E. Grant, USA, Kaibab National Forest, Arizona, Coconino County, G. Thomas Robbins 2190; Phlox pilosa L., USA, Piatt County, along Sangamon River, G. N. Jones 13684; Polemonium occidentale Greene, USA, Idaho, Lemhi Forest, R. B. Johnson 137

Primulaceae (0/6)'; Dionysia oreodoxa Bornm., Iran, Kerman Prov., J. Bornmüller 3873; Dodocatheon alpinum (A. Gray) Greene, USA, California, South Lake, J. Bouharmont 8711; Primula calliantha Franch., China, Yunnan, District of Chung-tien, J. F. Rock 24643; P. szechuanica Pax, China, Djesi-La, Djesi-Longba, J. F. Rock 17713 
Table 1 continued

Family Genera and specimens tested for Al accumulation

Roridulaceae

Sapotaceae

Sarraceniaceae

Sladeniaceae

Styracaceae

(including

Halesiaceae)

\section{Symplocaceae}

Ternstroemiaceae

Tetrameristaceae

Theaceae

Theophrastaceae (including

Samolaceae)
$(0)^{3}$; Roridula dentata L., South Africa, Cape Province, A. L. Grant 3476; R. gorgonias Planch., South Africa, Vogelgat, R. Schlechter 9546

(0/2) ${ }^{1}$; (0/12) ${ }^{4}$; Argania spinosa (L.) Skeels, Morocco, Cap Rhiz, Tamri, J. Lewalle 6909; Beccariella baueri (Montrouz.) Aubrév., New Caledonia, Lukuma, Ngoye, R. Schlechter 15260; Englerophytum kennedyi Aubrév., Cameroon, Buea-Douala, D. Thomas 2248; Ganua (1/1)5; Isonandra sp., Sri Lanka, near base of Adamspeak rock, Maskeliya, trail from Moray Estate, A. Kostermans 27571; Labourdonnaisia madagascariensis Pierre ex Baill., Madagascar, Antalaha, between Amelabe, and Ambohitralanan, R. Capuron 27747-SF; Lecomtedoxa klaineana (Pierre ex Engl.) Dubard, Gabon, Ogooue-Maritime, Setté Cama, G. McPherson 16835; Madhuca sp., Borneo, Tawao, Elphinstone Prov., A. D. E. Elmer 21571; M. fulva (Thwaites) J. F. Macbride, Sri Lanka, Kanneliya forest near Hiniduma, Galle District, Kostermans 27630; M. sericea (Miq.) H. J. Lam, Sumatra, Masihi Forest Reserve, Asahan, East Coast, B. A. Krukoff 4144; Manilkara decrescens T. D. Penn., Brazil, Rod. BA-365, Mun. Buritizeiro, Minas Gerais, G. and M. Hatschbach and J. M. Silva 62052; Mimusops subsericea Mart., Brazil, Herbarium Martii, Galeottii, BR-S.P. 834 484; Omphalocarpum bomanehense De Wild., Democratic Republic of Congo-Kinshasa, Gimbi Vallée de la Fuka, L. Toussaint 437; Palaquium $(1 / 1)^{5}$, P. sp., Sri Lanka, Botanic Garden of Peradeniya, Kostermans 27515; P. canaliculatum (Thwaites) Engl., Sri Lanka, Red Cliff on seacoast near Weligama, A. Kostermans 28565; Pouteria reticulata (Engl.) Eyma subsp. surinamensis T. D. Penn., Surinam, BR-S.P. 834 483; Pradosia lactescens (Vell.) Radlk., Brazil, Rio Pequeno, Mun. Antonina, Paraná, G. Hatschbach 41775; Sideroxylon buxifolium Hutch., Sultanate of Oman, Wadi Mistal, Habish, S. A. Ghazanfar 1944; S. lanuginosum Michx. subsp. rugidum (A.Gray) T. D. Penn., Mexico, Monterey, C. G. Pringle 4506; Synsepalum dulcificum (Schum. and Thonn.) Daniell, Sri Lanka, Bot. Garden Peradeniya, A. Kostermans 27359; Tridesmostemon claessensi De Wild., Democratic Republic of Congo-Kinshasa, Yangambi, C. Donis 3388; Vitellariopsis kirkii (Baker) Dubard, Tanzania, Tanga Prov., Mkaramo, Mkwaja, R. E. S. Tanner 3176

$(0 / 1)^{3}$; Darlingtonia californica Torr., USA, California, Mt. Eddy, Siskiyou County, E. B. Copeland 3812; Sarracenia psittacina Michx., USA, Georgia, St. Mary’s, Rugel 14

Sladenia $(0 / 1)^{3}$; Ficalhoa laurifolia Hiern, Zambia, Isoka district, A. Angus 802

$(0 / 7)^{3}$; Alniphyllum fortunei Makino, China, Jiangkou Xian, Mt. Fanjing Shan, Sino-American Guizhou Botanical Expedition 945; Bruinsmia styracoides Boerl. and Koord., New Guinea, Geelvinckbaai, N.E. Coast Japan Isl., Woda, Ch. Koster BW 11240; Halesia carolina L., USA, Creek bank, Gap Creek Road, River Falls, South Carolina, Greenville County, N. E. Mullens and C. L. Rogers 67036; H. diptera L., USA, Possum and Teal Islands, Savannah River, South Carolina, Jasper County, S. W. Leonard 2655; Sinojackia rehderiana Hu, China, Yizhang, Hunan, S. H. Chen 1947; Styrax glabratum (Spruce) Schott, Brazil, Paraná, Pontal do Sul, Mun. Paranaguá, Hatschbach and A. R. Campos 59759; S. pulverulenta Michx., USA, Florida, near Jacksonville, A. H. Curtis 1768; S. warscewiczii Perkins, Costa Rica, J. J. Cooper 10321

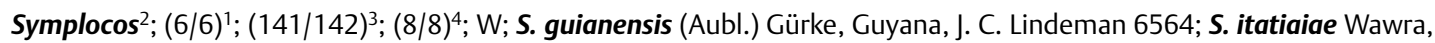
Brazil, Santa Catarina, Serra da Boa Vista, São José, Reitz and Klein 9858

Adinandra (21/24) ${ }^{3}$; A. dumosa Jack, Sumatra, Masihi Forest Reserve, Asahan, East Coast, B. A. Krukoff 4255; Anneslea $(0 / 2)^{3}$; Archboldiodendron $(0 / 1)^{3}$; Cleyera $(5 / 6)^{3}$; Eurya $(2 / 2)^{1} ;(1 / 1)^{2} ;(21 / 21)^{3} ;(1 / 1)^{5}$; E. acuminata DC., Sumatra, Hoeta Padang, Asahan, East Coast, B. E. Krukoff 4404; E. chinensis R. Br., Sri Lanka, Thwaites 784, BR-S.P. 834 450; Freziera $(12 / 16)^{3} ;$ F. undulata (Sw.) Willd., Grenada, W. E. Broadway 4474z; Symplococarpon $(2 / 2)^{3}$; Ternstroemia $(0 / 1)^{1} ;(1 / 2)^{4}$; $(7 / 89)^{3}$; T. japonica Thunb., Japan, Honshu, Mt. Kiyosumi in Awa, N. Naruyama and K. Okamoto 1619; Visnea $(0 / 1)^{3}$, V. mocanera L. f., Teneriff, Crux de Taganana, Cumbre, J. Bornmüller 927

Tetramerista $(0 / 1)^{3}$

Camellia $(3 / 3)^{1} ;(3 / 3)^{2} ;(27 / 27)^{3}$; W; Franklinia $(0 / 1)^{3}$; Gordonia $(25 / 32)^{3} ;(1 / 1)^{4} ;(2 / 2)^{5}$; W; Pyrenaria $(12 / 12)^{3}$, W; Schima $(4 / 10)^{3},(1 / 1)^{5}$, S. wallichii (DC.) Choisy, Malaysia, Sarawak, Kuching, Mt. Serapi, J. L. Panero et al. 6267; Stewartia $(1 / 1)^{1},(1 / 1)^{2},(5 / 5)^{3}$

(0)3; Clavija longifolia Ruiz and Pav., origin unknown, Curarina Sacha, J. Schunke-Vigo 12180; Deherainia smaragdina (Linden) Decne., British Honduras, Eldorado, Punta Gada, W. A. Schipp 1023; Jacquinia arborea Vahl, origin unknown, BR-S.P. 834 503; J. armillaris Jacq., Venezuela, Prov. de Caraboba, J. Linden 1553; Samolus ebracteatus Kunth, USA, Florida, A. H. Curtis 1811; S. praviflorus Raf., Japan, Honshu, Oundari, Torami in Kazusa, K. Hisauchi 1053

\section{The phylogeny of Al accumulation}

Although a limited number of species were tested in this study, the consistent presence or absence of $\mathrm{Al}$ accumulation in most families of the Ericales is remarkable. The distribution of $\mathrm{Al} \mathrm{ac}-$ cumulating families was plotted on three trees that are based on recent molecular phylogenetic studies (Anderberg et al., 2002; Bremer et al., 2002; Geuten et al., 2004; Figs.1-3). These molecular analyses provide strong support for the following clades: a balsaminoid, primuloid, ternstroemioid (Penthaphylacaceae sensu APG II, 2003), and ericoid group. Nonaccumulators seem to characterise the families that constitute the primitive clade of Balsaminaceae, Marcgraviaceae,
Pellicieraceae, and Tetrameristaceae. The feature is also absent in the Polemoniaceae-Fouquieriaceae clade, as well as in the well-supported ericoid clade (including Ericaceae, Cyrillaceae, Clethraceae, Roridulaceae, Sarraceniaceae, Actinidiaceae). On the other hand, the $\mathrm{Al}$ accumulating families appear to be more or less closely related, but there is no evidence for a single origin of $\mathrm{Al}$ accumulation in the order. It should be emphasized that exact interfamilial relationships in Ericales remain unclear and this obviously hinders any discussion on the evolution of the character in this group. 


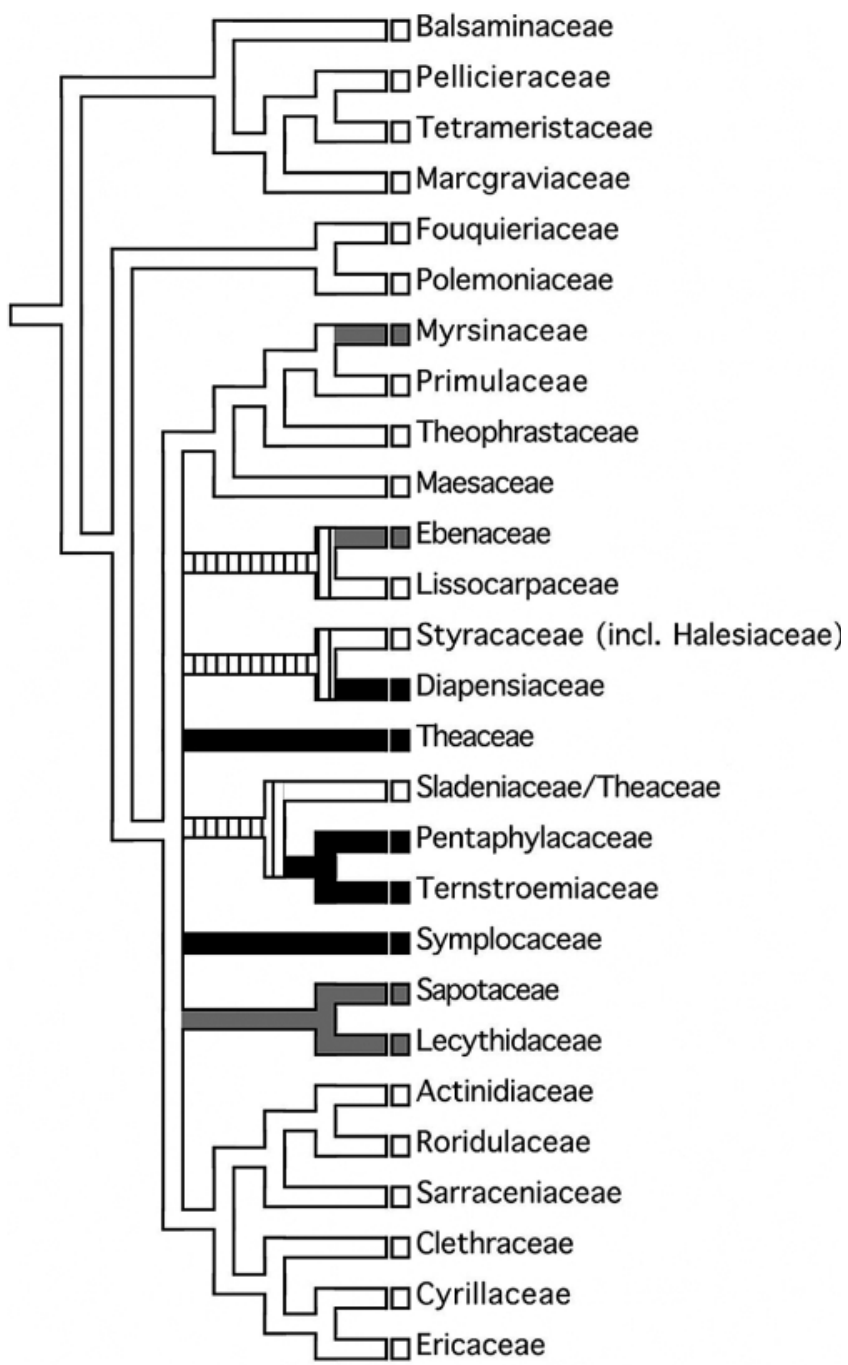

Al accumulation

unordered

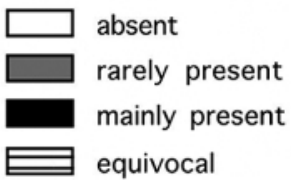

Fig. 1 Distribution of Al accumulation in the Ericales, plotted on the parsimony jackknife tree based on analysis of molecular data from five genes (Anderberg et al., 2002).

A possible relation between the Ternstroemiaceae and Pentaphylaceae is supported by the common occurrence of $\mathrm{Al} \mathrm{accu-}$ mulation. The Ternstroemiaceae and Sladeniaceae are included in an enlarged Pentaphylacaceae s.l. according to APG II (2003). Al accumulation is absent in Sladenia (Sladeniaceae) according to Chenery (1948 b). A lack of high Al levels is also found in Ficalhoa, which came out as a sister group of Sladenia in the molecular analyses of Anderberg et al. (2002). Therefore, absence of $\mathrm{Al}$ accumulation may support the basal position of Sladenia and Ficalhoa within the Pentaphylacaceae s.l., but non-accumulators are also found within several Ternstroemiaceae.

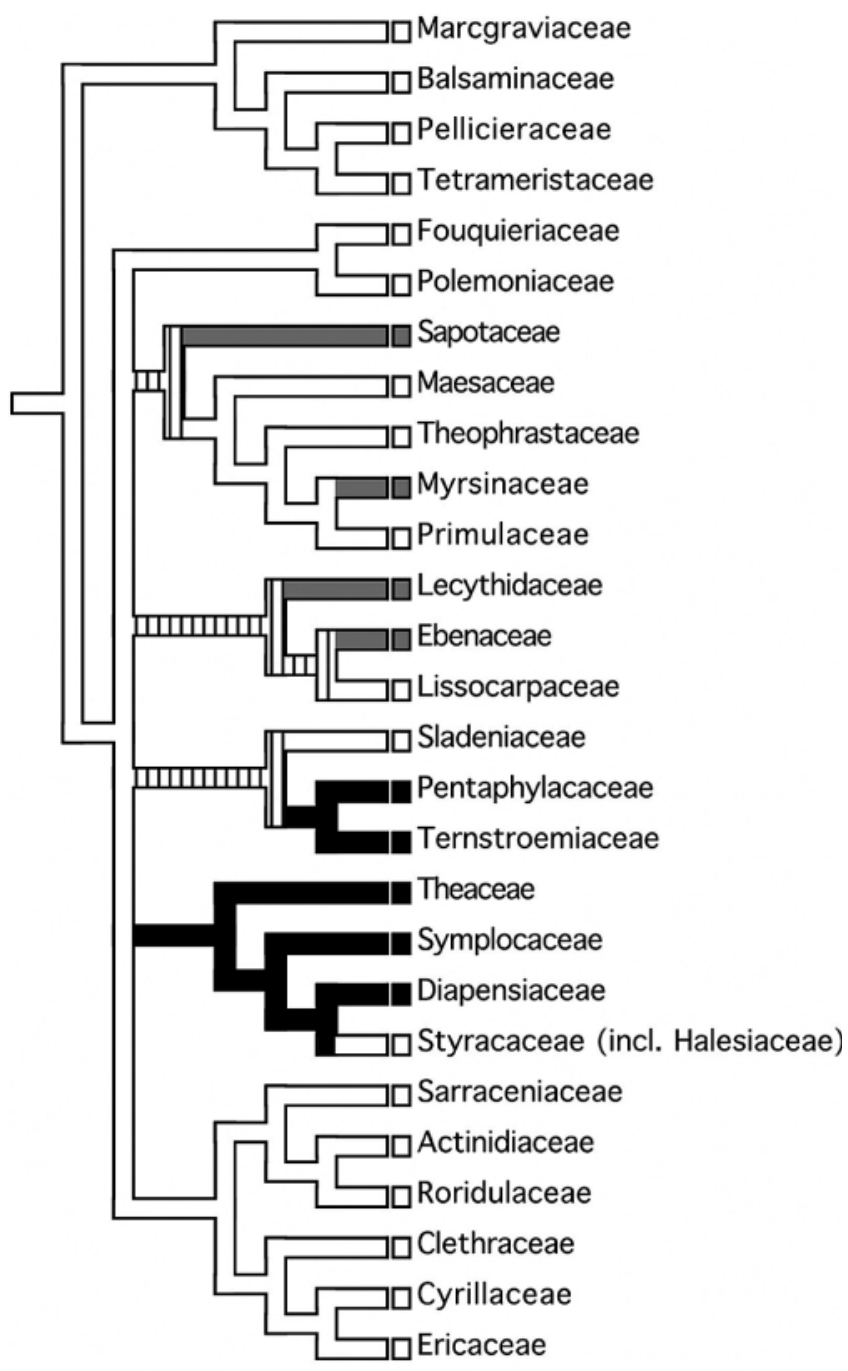

Al accumulation unordered

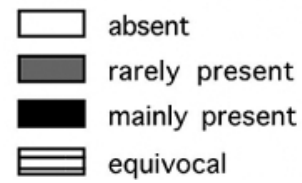

Fig. 2 Distribution of Al accumulation in the Ericales, plotted on the strict consensus tree based on analysis of molecular phylogenetic data from six markers (Bremer et al., 2002)

As far as we know, the highest content of $\mathrm{Al}$ recorded in any plant is 72240 ppm in Symplocos spicata Roxb. (Symplocaceae) (von Faber, 1925). The bark and leaf tissues of Symplocos species have been used for centuries in traditional dyeing technologies as the high Al levels were used as a mordant instead of alum (Hutchinson, 1943). The taxonomic position of Symplocos has recently been discussed in Caris et al. (2002). Geuten et al. (2004) concluded that the Theaceae sensu APG II (2003) are the closest relatives of the Symplocaceae. The occurrence of strong Al accumulation in Symplocos may confirm its affinity with the Theaceae. It is clear that Al accumulation in the Theaceae is not restricted to the genus Camellia, but also commonly 


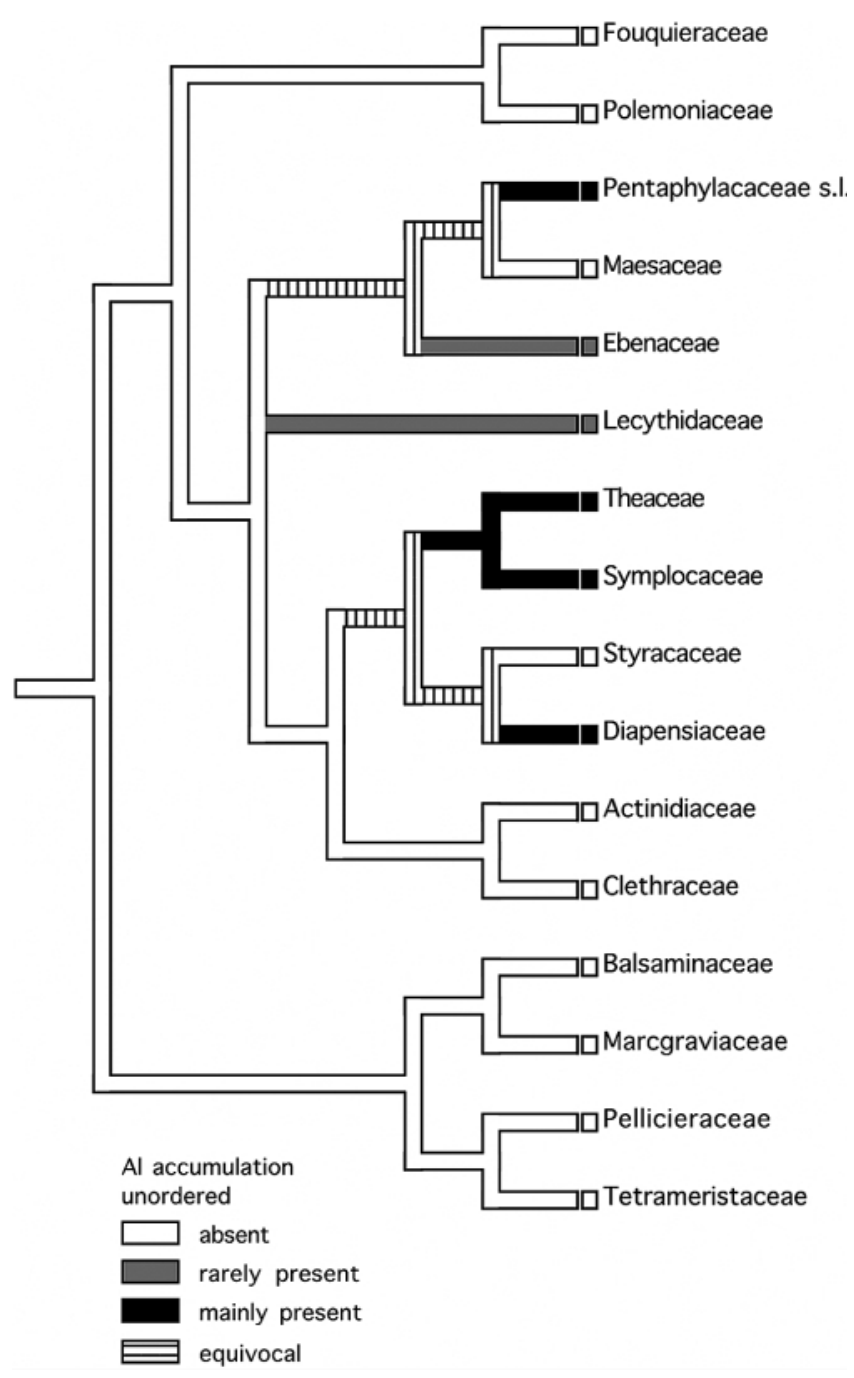

Fig. 3 Distribution of Al accumulation in the Ericales, plotted on the consensus topology of a hierarchical model Bayesian analysis (Geuten et al., 2004); Pentaphylacaceae s.I. include Ternstroemiaceae and Sladeniaceae.

present in Gordonia, Pyrenaria, Stewartia, and to a lesser extent in Schima.

The majority of $\mathrm{Al}$ accumulating plants are woody shrubs or trees from tropical areas (Chenery and Sporne, 1976; Jansen et al., 2002 a, 2004). The Diapensiaceae are remarkable Al accumulators, which include perennial herbs and small shrubs from cold to temperate areas in chiefly alpine regions of North America and Eurasia. Although Al accumulation is seemingly present in all species of this family, the single species of Shortia and Galax tested were negative. The unusual presence of $\mathrm{Al}$ accumulation in this mainly herbaceous family may reflect a possible relationship with other $\mathrm{Al}$ accumulating families. Most molecular analyses suggest a strong relationship of the Diapensiaceae with the non-accumulating Styracaeae (Soltis et al., 2000; Anderberg et al., 2002; Bremer et al., 2002; Geuten et al., 2004). While a possible - though weakly supported - sister group relationship of the DiapensiaceaeStyracaceae clade with the Symplocaceae was proposed by Soltis et al. (2000) and Bremer et al. (2002). Geuten et al.
(2004) found strong support for a relationship of the Styracaceae-Diapensiaceae with the Theaceae-Symplocaceae (Fig. 3). Together with the morphological evidence for a relationship between the Symplocaceae and Theaceae, this could lead to the assumption that the strong $\mathrm{Al}$ accumulating families Diapensiaceae, Symplocaceae, and Theaceae share a common ancestry. Nevertheless, more studies, both morphological and molecular, are needed to increase support for these relationships.

Contrary to the systematic significance of $\mathrm{Al}$ accumulation in the strong accumulating Ericales, there is so far no evidence illustrating that the very rare occurrence of $\mathrm{Al}$ accumulation shows any taxonomic significance within the Lecythidaceae (including Scytopetalaceae), Sapotaceae, Ebenaceae, and Myrsinaceae. Although records in the Sapotaceae are restricted to the genera Ganua and Palaquium, which both belong to the tribe Isonandreae (Pennington, 1991), the Sapotaceae tested here suggest that $\mathrm{Al}$ accumulation is absent in this family. Moreover, the Al accumulating genera Brazzeia and Pierrina belong to the same subfamily, Rhaptopetaloideae (Scytopetalaceae), but absence of $\mathrm{Al}$ accumulation in Rhaptopetalum suggests that this feature does not characterise the Rhaptopetaloideae entirely (Appel, 2004).

\section{Some ecophysiological aspects of Al accumulation}

It has been illustrated that the uptake of high $\mathrm{Al}$ concentrations has a beneficial effect on the growth of the tea bush (Chenery, 1955; Konishi et al., 1985; Konishi, 1992; Tsuji et al., 1994). Growth and phosphorus (P) uptake in tea plants are enhanced by $\mathrm{Al}$ application in hydroponic culture. Konishi et al. (1985) demonstrated that Al stimulates P uptake under low P conditions and alleviates $\mathrm{P}$ toxicity under high $\mathrm{P}$ conditions. This suggests that Al plays a regulatory role in the effective uptake and utilization of P. Matsumoto et al. (1976) assumed that the increased growth of tea shoots depends on the positive effect of $\mathrm{Al}$ on the roots. Moreover, Chenery (1955) reported that tea plants grown in alkaline soils are very stunted and their leaves are chlorotic. Brushing the leaves with an Al solution, however, results in complete recovery. Therefore, it is clear that $\mathrm{Al}$ has some beneficial effect on the shoots of tea plants, but the exact physiological mechanisms remain unclear. It would be interesting to investigate whether this stimulating effect also occurs in other $\mathrm{Al}$ accumulating Ericales. At present, similar results have been reported for Melastoma (Melastomataceae), Miconia (Melastomataceae), Hydrangea (Hydrangeaceae), and Vochysia (Vochysiaceae), which are all Al accumulating genera (Machado, 1985; Haridasan, 1988; Osaki et al., 1997; Watanabe et al., 1997).

There is usually a clear coincidence between the ability to accumulate and detoxify high internal Al levels in aerial parts of the plant and distribution of substances that have a strong affinity to bind Al. Therefore, tannins, flavonols (e.g., quercetin, myricetin, kaempferol), flavonol-3-ols (e.g., catechin), and anthocyanidins (e.g., delphinidin) may be implicated in vacuolar storage of $\mathrm{Al}$ (Barceló and Poschenrieder, 2002). It has been demonstrated that $\mathrm{Al}$ is transported through the stem of tea plants as an Al-Fe complex, but is accumulated as an Al-catechin complex in the leaves (Nagata et al., 1992; Liang et al., 1996). Higher levels of $\mathrm{Al}$ in the cell walls of tea leaves are also associated with increased levels of Si and Mg (Echlin, 1999). 
However, the chemical speciation in other Al accumulating Ericales is entirely unknown.

Also, there could be interactions between $\mathrm{Al}$ response mechanisms and mycorrhizal associations in plant roots, of which different types have been found in some families in the Ericales (Shaw, 1987). Ericoid mycorrhizae, for instance, characterise the Ericaceae s.l. (including Empetraceae and Epacridaceae), and arbuscular mycorrhizae have been found in the Clethraceae (Cullings, 1996; Kubota et al., 2001). Mycorrhizae clearly play an important role in calcifuges like the Ericaceae s.l., because they allow them to establish in, and often dominate, acidic environments such as heathlands, ecosystems of low mineral availability, high humic accumulation, and limited nitrogen availability (Read, 1991). Most Ericaceae are exposed to high concentrations of available $\mathrm{Al}$, Fe, and $\mathrm{Mn}$. The regulation of $\mathrm{Fe}, \mathrm{Cu}$, and $\mathrm{Zn}$ by ericoid mycorrhizal plants has been studied by Shaw et al. (1990) and Bradley et al. (1981, 1982), but very little seems to be known about their effect on Al. Martin et al. (1994) showed that Al was rapidly taken up and accumulated into polyphosphate complexes in the vacuoles of the mycorrhizal basidiomycete Laccaria bicolor Marie (Orton). Although there are also reports of enhancement of micronutrient uptake in the shoot by mycorrhizal plants, we suggest that mycorrhizae form an effective external resistance mechanism in several Ericales, especially in Al-excluding representatives of the ericoid clade.

Finally, we understand very little about the functional significance of $\mathrm{Al}$ accumulation in plants. $\mathrm{Al}$ accumulation does not appear to be an essential strategy, but one of several options that plants may use to deal with Al toxicity in acid soils (Haridasan and Araújo, 1987). It has also been suggested that Al accumulation in leaves may lower the nutritional value for herbivores and thus acts as a chemical defence against animals (Nascimento, 1989, Nascimento et al., 1990).

\section{Acknowledgements}

We thank Anja Vandeperre (K.U. Leuven) for assistance with the aluminium tests. The director of the National Botanic Garden of Belgium is acknowledged for the use of herbarium material. Research at the Laboratory of Plant Systematics is supported by grants from the Research Council of the K.U.Leuven (OT/01/25) and the Fund for Scientific Research - Flanders (Belgium) (G.0104.01, 1.5.069.02, and 1.5.061.03). SJ is a postdoctoral fellow of the Fund for Scientific Research - Flanders (Belgium) (F.W.O. - Vlaanderen), KG has a bursary from the Research Council of the K.U.Leuven (OT/01/25), and NP is a postdoctoral fellow of the K.U.Leuven (PMD/02/113).

\section{References}

Anderberg, A. A., Rydin, C., and Källersjö, M. (2002) Phylogenetic relationships in the order Ericales s.l.: analysis of molecular data from five genes from the plastid and mitochondrial genomes. American Journal of Botany 89, 677-687.

APG II (2003) An update of the Angiosperm Phylogeny Group classification for the orders and families of flowering plants: APG II. Botanical Journal of the Linnean Society 141, 399-436.

Appel, O. (2004) Scytopetalaceae. In The Families and Genera of Vascular Plants, Vol. VI: Flowering Plants. Dicotyledons: Celastrales, Oxalidales, Rosales, Cornales, Ericales (Kubitzki, K., ed.), Berlin, Heidelberg: Springer-Verlag, pp.426-430.
Barceló, J. and Poschenrieder, C. (2002) Fast root growth responses, root exudates, and internal detoxification as clues to the mechanisms of aluminium toxicity and resistance: a review. Environmental and Experimental Botany 48, 75-92.

Bradley, R., Burt, A. J., and Read, D. J. (1981) Mycorrhizal infection and resistance to heavy metal toxicity in Calluna vulgaris. Nature 292, $335-337$.

Bradley, R., Burt, A. J., and Read, D. J. (1982) The biology of mycorrhiza in the Ericaceae. VIII. The role of mycorrhizal infection in heavy metal tolerance. New Phytologist 91, 197-209.

Bremer, B., Bremer, K., Heidari, N., Erixon, P., Olmstead, R. G., Anderberg, A. A., Källersjö, M., and Barkhordarian, E. (2002) Phylogenetics of Asterids based on 3 coding and 3 non-coding chloroplast DNA markers and the utility of non-coding DNA at higer taxonomic levels. Molecular Phylogenetics and Evolution 24, 274- 301.

Caris, P., Ronse Decraene, L.-P., Smets, E., and Clinckemaillie, D. (2002) The uncertain systematic position of Symplocos (Symplocaceae): evidence from a floral ontogenetic study. International Journal of Plant Sciences 163, 67-74.

Chenery, E. M. (1946) Are Hydrangea flowers unique? Nature 158, 240-241.

Chenery, E. M. (1948 a) Aluminium in plants and its relation to plant pigments. Annals of Botany 12,121 - 136 .

Chenery, E. M. (1948 b) Aluminium in the plant world. Part I, General survey in dicotyledons. Kew Bulletin 2, 173-183.

Chenery, E. M. (1955) A preliminary study of aluminium and the tea bush. Plant Soil 6, 174-200.

Chenery, E. M. and Sporne, K. R. (1976) A note on the evolutionary status of aluminium-accumulators among dicotyledons. New Phytologist 76, $551-554$.

Cullings, K. W. (1996) Single phylogenetic origin of ericoid mycorrhizae within the Ericaceae. Canadian Journal of Botany 74, 18961909.

Echlin, P. (1996) Distribution of aluminium in the cells of developing leaves of the tea plant as measured by low-temperature X-ray microanalysis. Scanning 18, 197-198.

Echlin, P. (1999). Low-voltage energy-dispersive X-ray microanalysis of bulk biological materials. Microscopy and Microanalysis 4, $577-584$.

Exley, C. (2001) Aluminum and Alzheimer's Disease. The Science that Describes the Link. New York: Elsevier Science.

Exley, C. (2003) A biogeochemical cycle for aluminium? Journal of Inorganic Biochemistry 97, 1-7.

Flaten, T. P. and Ødegård, M. (1988) Tea, aluminium and Alzheimer's disease. Food and Chemical Toxicology 26, 959-960.

Flaten, T. P. (2002) Aluminium in tea - concentration, speciation and bioavailability. Coordination Chemistry Reviews 228, 385- 395.

Foy, C. D., Chaney, R. L., and White, M. C. (1978) The physiology of metal toxicity in plants. Annual Review of Plant Physiology 29, $511-566$.

Geuten, K., Smets, E., Schols, P., Yuan, Y.-M., Janssens, S., Küpfer, P., and Pyck, N. (2004) Conflicting phylogenies of balsaminoid families and the polytomy in Ericales: combining data in a Bayesian framework. Molecular Phyologenetics and Evolution 31, 711-729.

Haridasan, M. (1988) Performance of Miconia albicans (Sw.) Triana, an aluminium accumulating species, in acidic and calcareous soils. Communications in Soil Science and Plant Analysis 19, $1091-1103$.

Haridasan, M. and Araújo, G. M. (1987) Aluminium accumulating species in two forest communities in the cerrado region of central Brazil. Forest Ecology and Management 24, 15-26.

Hutchinson, G. E. (1943) The biogeochemistry of aluminum and of certain related elements. Quarterly Review of Biology 18, 1- 29.

Jansen, S., Broadley, M., Robbrecht, E., and Smets, E. (2002 a) Aluminium hyperaccumulation in angiosperms: a review of its phylogenetic significance. The Botanical Review 68, 235-269. 
Jansen, S., Dessein, S., Piesschaert, F., Robbrecht, E., and Smets, E. (2000a) Aluminium accumulation in leaves of Rubiaceae: systematic and phylogenetic implications. Annals of Botany 85, $91-101$.

Jansen, S., Robbrecht, E., Beeckman, H., and Smets E. (2000 b) Aluminium accumulation in Rubiaceae: an additional character for the delimitation of the subfamily Rubioideae? International Association of Wood Anatomists Journal 21, 197 - 212.

Jansen, S., Watanabe, T., Dessein, S., Robbrecht, E., and Smets, E. (2003) A comparative study of metal levels in leaves of some Al accumulating Rubiaceae. Annals of Botany 91, 657-663.

Jansen, S., Watanabe, T., Dessein, S., Robbrecht, E., and Smets, E. (2004) The evolution of aluminium accumulation in angiosperms. In Evolution of Plant Physiology. From Whole Plants to Ecosystems (Hemsley, A. and Poole, I., eds.), London: Elsevier Academic Press, $467-479$.

Jansen, S., Watanabe, T., and Smets, E. (2002 b) Aluminium accumulation in leaves of 127 species in Melastomataceae with comments on the order Myrtales. Annals of Botany 90, 53-64.

Kochian, L. V. (1995) Cellular mechanisms of aluminum toxicity and resistance in plants. Annual Review of Plant Physiology and Plant Molecular Biology 46, 237-260.

Konishi, S. (1992) Promotive effects of aluminium on tea plant growth. Japanese Agricultural Research Quarterly 26, 26-33.

Konishi, S., Miyamato, S., and Tazi, T. (1985) Stimulatory effects of aluminium on tea plants grown under low and high phosphorus supply. Soil Science and Plant Nutrition 31, 361 - 368.

Kubota, M., McGonigle, T. P., and Hyakumachi, M. (2001) Clethra barbinervis in the Ericales forms arbuscular mycorrhizae. Phytopathology 91 (Suppl.), 118.

Kukachka, B. F. and Miller, R. B. (1980) A chemical spot-test for aluminum and its value in wood identification. International Association of Wood Anatomists Bulletin 1,104-109.

Liang, J.-Y., Shyu, T.-H., and Lin, H.-C. (1996) The aluminum complexes in the xylem sap of tea plant. Journal of the Chinese Agricultural Chemical Society 34, 695-702.

Machado, J. W. B. (1985) Acumulação de alumínio em Vochysia thyrsoidea Pohl. University of Brasília, Brasília: M.Sc. Thesis.

Maddison, W. P. and Maddison, D. R. (2000) MacClade: interactive analysis of phylogeny and character evolution, version 4.0. Sunderland, Massachusetts: Sinauer Associates Inc.

Martin, F., Rubini, P., Cote, R. and Kottke, I. (1994) Aluminium polyphosphate complexes in the mycorrhizal basidiomycete Laccaria bicolor: A 27Al-nuclear magnetic resonance study. Planta 194, $241-246$.

Marschner, H. (1995) Mineral Nutrition of Higher Plants, 2nd ed. London: Academic Press.

Masunaga, T., Kubota, D., Hotta, M., and Wakatsuki, T. (1998) Mineral composition of leaves and bark in aluminum accumulators in a tropical rain forest in Indonesia. Soil Science and Plant Nutrition $44,347-358$.

Matsumoto, H., Hirasawa, E., Morimura, S., and Takahashi, E. (1976) Localisation of aluminium in the tea leaf. Plant Cell Physiology 17, 627-631.

Memon, A. R., Chino, M., and Yatazawa, M. (1981) Micro-distribution of aluminum and manganese in the tea leaf tissues as revealed by $\mathrm{x}$-ray microanalyzer. Communications in Soil Science and Plant Analysis 12, $441-452$.

Nagata, T., Hayatsu, M., and Kosuge, N. (1993) Aluminium kinetics in the tea plant using ${ }^{27} \mathrm{Al}$ and ${ }^{19} \mathrm{~F}$ NMR. Phytochemistry $32,771-$ 775.

Nagata, T., Masahito, H., and Kosuge, N. (1992) Identification of aluminium forms in tea leaves by ${ }^{27} \mathrm{Al}$ NMR. Phytochemistry 31, $1215-1218$.

Nascimento, M. T. (1989) Herbivoria foliar em Vochysia divergens Pohl. Brasil Florestal 68, 51 - 84 .
Nascimento, M. T., Villela, D. M., and de Lacerda, L. D. (1990) Foliar growth, longevity and herbivory in two "cerrado" species near Cuiaba, MT, Brazil. Revista Brasileira de Botânica 13, 27-32.

Osaki, M., Watanabe, T., and Tadano, T. (1997) Beneficial effect of aluminum on growth of plants adapted to low pH soils. Soil Science and Plant Nutrition 43, 551 - 563.

Pennington, T. D. (1991) The Genera of Sapotaceae. Kew: Royal Botanic Gardens, New York: New York Botanical Gardens.

Read, D. J. (1991) Mycorrhizas in ecosystems. Experientia 47, 376 391.

Roy, A. K., Sharma, A., and Talukder, G. (1988) Some aspects of aluminum toxicity in plants. Botanical Review 54, 145-178.

Ruan, J. Y. and Wong, M. H. (2001) Accumulation of fluoride and aluminium related to different varieties of tea plant. Environmental Geochemistry and Health 23, 53-63.

Shaw, G. (1987) Iron and aluminium toxicity in the Ericaceae in relation to mycorrhizal infection. University of Sheffield, Sheffield, UK: Ph.D. Thesis.

Shaw, G., Leake, J. R., Baker, A. J. M., and Read, D. J. (1990) The biology of mycorrhiza in the Ericaceae. XVII. The role of mycorrhizal infection in the regulation of iron uptake by ericaceous plants. New Phytologist 115, $251-258$.

Smets, E. and Pyck, N. (2003) Ericales (Rhododendron). In Nature Encyclopedia of Life Sciences. London: Nature Publishing Group, http://www.els.net.

Soltis, D. E., Soltis, P. S., Chase, M. W., Mort, M. E., Albach, D. C., Zanis, M., Savolainen, V., Hahn, W. H., Hoot, S. B., Fay, M. F., Axtell, M., Swensen, S. M., Nixon, K. C., and Farris, J. S. (2000) Angiosperm phylogeny inferred from a combined data set of $18 \mathrm{~S}$ rDNA, $r b c \mathrm{~L}$, and $\operatorname{atpB}$ sequences. Botanical Journal of the Linnean Society 133 , $381-461$.

Tsuji, M., Kubai, T., and Konishi, S. (1994) Stimulatory effects of aluminum on the growth of cultured roots of tea. Soil Science and Plant Nutrition 40, $471-476$.

von Faber, F. C. (1925) Untersuchungen über die Physiologie der javanischen Solfataren-Pflanzen. Flora 118, 89-110.

Watanabe, T. and Osaki, M. (2002) Mechanisms of adaptation to high Al condition in native plant species growing in acid soils: a review. Communications in Soil Science and Plant Analysis 33, 1247 1260.

Watanabe, T., Osaki, M., and Tadano, T. (1997) Aluminum-induced growth stimulation in relation to calcium, magnesium and silicate nutrition in Melastoma malabathricum L. Soil Science and Plant Nutrition 43, 827-837.

Webb, L. J. (1954) Aluminium accumulation in the Australian-New Guinea flora. Australian Journal of Botany 2, 176- 197.

Wong, M. H., Fung, K. F., and Carr, H. P. (2003) Aluminium and fluoride in tea, with emphasis on brick tea and their health implications. Toxicology Letters 137, $111-120$.

Yoshii, Y. and Jimbo, T. (1932) Mikrochemischer Nachweis von Aluminium und sein Vorkommen im Pflanzenreiche. The Science Reports of the Tôhoku Imperial University 7, 65-77.

\section{S. Jansen}

Laboratory of Plant Systematics

Institute of Botany and Microbiology

K.U.Leuven

Kasteelpark Arenberg 31

3001 Leuven

Belgium

E-mail: steven.jansen@bio.kuleuven.ac.be

Section Editor: F. R. Scarano 